\title{
Employers' Requirements on Labour Force in the South Moravian Region
}

\author{
- Horñáček Josef, Zelenková Iveta
}

\begin{abstract}
This article is focused on identifying employers' requirements on workforce in the South-Moravian Region and assessing whether or not the requirements are referring mainly to education, level of qualification and work experience or to competencies. The research is based on the Swedish approach to monitoring employers' requirements on workforce, which uses competency-based qualitative interviewing. The Swedish scenario of a semi-structured interview was adapted to Czech conditions. 200 employers in the South Moravian Region were interviewed. Pronounced requirements on workforce refer mainly to education, professional qualifications and experience and the resulting specific professional competencies. To a large extent the requirements were focused on values, attitudes and character traits. The general specialized competencies and soft skills were also mentioned, but mostly as last in order. The requirements varied according to the size and orientation of the company and the nature of the vacancy.
\end{abstract}

Keywords: competency, skills, labour market, recruitment

JEL Classification: J23

\section{INTRODUCTION}

Motto:

"While earlier it was almost natural that capital would remain unchanged and too easy a movement of capital was even probibited by law, nowadays it is hardly possible to follow the capital; such is the number of transformations, such is the speed of investing capital in a company and withdrawing it again to be placed elsewhere, and that not for a long time. Therefore, it is necessary for workers to be able to follow it, thus to be able to work in different professions."

Émile Durkheim

Although the development often followed different directions than Émile Durkheim had imagined, after more than one hundred and ten years it is not necessary

to modify his thoughts mentioned in the motto of this article. Perhaps we would only add new knowledge of the requirements posed not only by the capital but by the work itself. Capital is not directed towards available workforce, but towards suitable workforce.

In the recent decades, the term competencies is increasingly being used in connection with the changing labour market, increasing demands on cooperation between production and administrative organizations on one side and educational organizations on the other, increasing globalization and the transition to a knowledge society. In different contexts we mention gen- 
eral competencies, soft competencies, transversal competencies, multiple competencies or key competencies, always struggling with the ambiguous meaning of the term itself and with diverse understanding of the term in different environments or national systems. In this study we decided to ascertain whether employers, when formulating requirements on the workforce, are able to use terms related to the qualification and education of their future workers as well as to the competencies connected directly to the personality of a particular individual or to the job position they take.

\section{SOCIAL PROBLEM}

The matching process on the labour market (LM) was traditionally based on defined categories of qualification and profession. With the pressure on maintaining and increasing competitiveness, together with increasing productivity, the categories of occupation and skills become gradually blurred, which has a negative impact on the effectiveness of intermediation based on these categories. Consequently, the monitoring and analysis of the LM in the Czech Republic mainly focuses on identifying qualification and professional needs, whereas for example in Sweden as well as in Austria both the employers' demand and candidates' offers are increasingly defined in terms of competencies.

Formulating the supply and demand on the LM in terms of qualifications and professions, perceived differently by different actors, possibly belongs to the factors limiting the effectiveness of filling vacancies with job seekers. As a result the number of the unemployed is growing and the employers are less willing to cooperate with representatives of public employment services. Identifying the competencies the potential employers need and consequently either directly assigning suitable candidates or allowing suitable candidates to acquire the required competencies is one of the possible ways to increase employment (cf. Klimplová, 2010; Winkler, Klimplová \& Vrbková, 2008).

\section{RESEARCH OBJECTIVES}

Our research was based on the assumption that employers, among diversely formulated requirements on the workforce, also formulate requirements on working competencies of individual workers. In order to allow the use of competencies to match labour supply and demand, it is necessary to identify and develop them with regard to existing individual and social conditions. This influences the matching process, since it includes not only factors of the current supply and demand on the LM, but also factors affecting the quality of the workforce in the medium and long term. New possibilities to develop the workforce bring different forms of formal, non-formal (provided within job position) and informal (integral part of everyday life) learning. Novotný (2006) points out that the crucial determinant of adult motivation and participation in education lies in their working and professional context, with training and development activities being more frequent with the growing level of achieved qualification. In brief, workers, who are high school or university graduates, are more likely to participate in development activities than workers with elementary education level or a vocational certificate. This further complicates arranging a suitable vacancy for groups of lower education levels. 
We decided to ascertain whether employers, when formulating requirements on the workforce, use terms referring mainly to education, level of qualification and work experience or whether they equally use terms related to competencies directly or indirectly connected to the personality of a particular individual. We thus arrived at the following wording of the main research question: What are the employers' requirements on workforce?

Answering this question should reveal the way of working with job seekers in the matching process and strengthen their ability to find an appropriate job opportunity. At the same time it should help raise awareness of the demand side on the LM, and consequently improve the conditions of filling vacancies with job seekers in the short term. In the medium and long term the acquired information may lead to improved planning and targeting of active employment policy programmes including requalification and other forms of education in the region. Better knowledge of the LM demands could also support the activities of various public institutions and initiate social investment into human capital, e.g. on the part of local governments. By meeting the information needs to flexibly fill vacancies with suitable workforce, we aim at bringing qualitative changes to the activities of public employment services. The application aim consists of ensuring the transition from randomly filling vacancies with job seekers to a systematic filling based on better information and reinforced emphasis on individual and targeted character of the workforce supply. The process of flexible filling of vacancies with suitable workforce is hereafter called active matching (AM).

\section{COMPETENCIES AS A WAY TO RECONCILE DEMAND AND SUPPLY ON THE LM}

Our turbulent times force companies to respond flexibly to any changes. The same applies to the area of human resources, where the demands on employees shift from formal qualification to informal qualification. Formal qualification is a formal outcome of an assessment and validation process which is obtained when a competent body determines that an individual has achieved learning outcomes to a given standard, is expressed in a formal document (certificate, degree, diploma or award) and is based on norms and specifications regulating its award. Employers' requirements tend to be more specific and may specify the main jobs that people do by describing professional tasks and activities (formal, professional qualification as described above) as well as the competencies typical of an occupation (informal, generic qualification), (Cedefop, 2009). Job analysis is performed to determine what people do in the job and what knowledge, skills, abilities, and other characteristics are required to do the job well - aggregated together as "competencies" (Thomas, 2010). Therefore we focused on the analysis of competency requirements. The main difference between a competency-based approach to monitoring the employers' requirements and the traditional approach is the fact that the competency-based approach highlights various knowledge, skills, abilities, values and attitudes a person needs to perform their work well, whereas the traditional approach tends to emphasize formal qualifications and experience as prerequisites for good work performance.

Competencies have many different meanings and definitions. In this text we adhere to the definition set out by Stabler and Hirsch (1995 in: Horton, Hondeghem \& Farnham, 2002), that com- 
petencies are skills, knowledge, experience, attitudes and behaviour an individual needs to efficiently perform their work. In this context, English distinguishes between a "competency" and a "competence" (Horton, Hondeghem \& Farnham, 2002; Moore, Cheng \& Dainty, 2002; Teodorescu, 2006; Mulder, Weigel \& Collins, 2007, Guthrie, 2009). “Competency” includes behavioural characteristics in a person that are causally related to efficient work performance (Boyatzis, 1982 in: Horton, Hondeghem \& Farnham, 2002). „Competence” is the ability to perform activities at a given position to a defined standard (Fletcher, 1991, in: Horton, Hondeghem \& Farnham, 2002). This distinction results from a different orientation. The first approach focuses on the inputs that help achieve successful work performance, whereas the second approach displays the output of competences. "Competency" concerns the people who perform work; "competence" concerns the job position and its current performance. Analysing "competence" therefore brings job description - what the job consists of; analysing "competency" brings the description of knowledge, skills, abilities, values and attitudes a person needs to perform their work (Horton, Hondeghem \& Farnham, 2002; Teodorescu, 2006; Mulder, Weigel \& Collins, 2007).

In this text we understand competencies rather in the sense of "competency" - during our interviews we asked what abilities and qualities should a worker have in a given position; we did not ask what the worker's job consists of. However some employers tend to talk more in terms of "competence", because it might be easier for them to determine the outputs - the way a successful work performance should look like (Cedefop, 2013).

We distinguish professional competencies, closely linked to a specific expertise, the mastery of which allows or facilitates the exercise of certain professions or occupations, and key (transferable) competencies that exceed the specific expertise, and seem necessary not only for successfully entering the LM but also for everyday life. Mastering these competencies should contribute to increasing the workers' flexibility in a broad sense, and thus the ability to perform a variety of specialized tasks or to alter professions without major problems, and facilitate the harmonizing of workers' abilities with employers' requirements.

This competency model is shared by the National Qualifications Framework, National Occupational Framework and other applications of employment services in the Czech Republic. Based on the above definition of Hirsch and Stabler (1995), we extended the model to values and attitudes. Also according to Kanfer and Ackerman (in: Elliot, Dweck, ed., 2005) performance of a job position is influenced by a number of factors including individual traits.

Tab. 1 - Competency model. Source: Ministry of Education, Youth and Sports (MŠMT, 2014), modified.

\begin{tabular}{|c|c|c|c|}
\hline \multirow{3}{*}{$\begin{array}{l}\text { Key } \\
\text { competencies }\end{array}$} & Values and at & udes & \multirow{3}{*}{$\begin{array}{l}\text { General } \\
\text { competencies }\end{array}$} \\
\hline & \multicolumn{2}{|c|}{ Soft competencies } & \\
\hline & \multirow{3}{*}{$\begin{array}{l}\text { Specialized } \\
\text { competencies }\end{array}$} & $\begin{array}{l}\text { General specialized } \\
\text { competencies }\end{array}$ & \\
\hline \multirow{2}{*}{$\begin{array}{l}\text { Professional } \\
\text { competencies }\end{array}$} & & \multirow{2}{*}{$\begin{array}{l}\text { Specific specialized } \\
\text { competencies }\end{array}$} & Knowledge \\
\hline & & & Activities \\
\hline
\end{tabular}


In this model, professional competencies are designated as specific specialized competencies. Specific specialized competencies may have a dual character:

- the character of knowledge - they include relevant knowledge and skills an individual acquired in the learning process that meet certain standards (these comprise knowledge that is not part of school education);

- the character of an activity - they include the ability to use the knowledge and skills to perform work tasks; these comprise experience supporting the development of these skills (e.g. electric cable dimensioning, securing and laying, planning a menu etc.), (MŠMT, 2014).

The key competencies comprise knowledge, skills, abilities and experience that exceeds the specific expertise on the one hand, and values and attitudes an individual uses to successfully manage work tasks and situations on the other (Veteška \& Tureckiová, 2008). In this context our model distinguishes:

- general specialized competencies, which include e.g. basic knowledge, skills and abilities and experience in the area of languages, IT, driving (driving license, category B), elementary legal and economic awareness etc.;

- soft competencies, which include effective communication, planning and organization of work, search for information and its understanding etc. (MŠMT, 2014);

- values and attitudes, which in particular comprise character traits.

In the interviews with employers we have therefore not only asked about the abilities a candidate should have, but also about their qualities. Personal traits are individual attributes that are either inherent or deeply ingrained, such as personality characteristics (Bowman, West, Beck, 2009). According to Pilařová (2009) a character is a set of psychological characteristics of a personality, which are manifested in the ethics of their behaviour and conduct (reflected in the values and attitudes). A character is not innate, it is developed in the course of life via education, self-education and other influences of society. Thus, in relation to work performance, ethical requirements, such as conscientiousness and responsibility, labour requirements, such as assiduity, diligence, sense of initiative and responsibility, relentlessness, punctuality etc. may appear, as well as requirements in the area of a positive attitude towards people, such as altruism, empathy, sociability, friendliness, etc. Such positive social attitudes enable individuals to create social values to the benefit of all people. Other qualities required may include perseverance, resistance to stress, and temperament characteristics such as control and management (self-control), (Pilařová, 2009).

To ensure the continuity of the process of bringing job seekers to the LM, it is especially necessary to reconcile the job seekers' knowledge, skills, abilities, values and attitudes with the employers' requirements and needs. However, it is equally important to provide job seekers with the opportunity to specify their notions of the world of work and of their possibilities in it, to encourage them to actively participate in the world of work and to support them with appropriate information on other possible qualifications and education (Dubois \& Rothwell, 2004). Knowing the competency model therefore allows to adequately fill vacancies with job seekers and to develop both specialized and key competencies in education and improve the ability of 
individuals to succeed in the LM, since employers require these broader general skills as well.

"Although the employers' demands for competencies often depend on the particular job, overall (i.e. regardless of the size or field of work of a certain company) it can be said that employers only slightly prioritise professional competencies over key competencies (i.e. should the employers divide $100 \%$ between these two types of competencies, then they attach on average $51,5 \%$ to the professional competencies and $48,5 \%$ to the key competencies in the secondary sector, in the tertiary sector it is 51,9\% and 48,1\% and in the quaternary sector 54,6 \% and 45,3\%). This is a rather important finding - that employers are aware of the importance of key competencies and that they consider them comparable with professional competencies." (Kalousková \&Vojtěch, 2008)

Despite these trends, the development of key competencies in the current Czech educational system is still weak. The role of key competencies in the system of lifelong learning is not appropriate either. Even the LM places little emphasis on monitoring a broader range of job competencies, the demand of which may be highly differentiated according to regions, the type and content of production in different organizations as well as to cultural and ethnic diversities in the LM.

Competency analysis is equally important for employers, employees and job seekers as well as for educational institutions and employment services. It enables employers to effectively recruit and select their employees, allowing "the right people to be in the right places" (Dubois \& Rothwell, 2004). This will strengthen the organizational performance and its competitive advantage. It will provide employees and job seekers with more accurate information defining the job position, allowing for easier orientation on the LM and for investments being made into educational activities corresponding to the LM requirements. For employment services, the importance of competency analysis lies in the indication of current and future needs on the LM and in efficient use of funds on scheduled educational / requalification programmes as well as in filling vacancies with adequate job seekers. It enables educational institutions to come up with offers corresponding to the LM requirements. Thus, competency analysis is a way to reconcile supply and demand in the LM.

\section{METHODOLOGY}

The research strategy chosen for this survey largely accentuates the qualitative approach to social research, when the informant's answers about economic situation and future demands on labour forces were interpreted. Questions in the interview were predominantly open, because we felt a lack of information to achieve in-depth categorization.

In most countries, monitoring employers' requirements is based on a quantitative approach using questionnaires or advertising analysis. Following the example of Sweden, we are using individual interviews to ascertain employers' requirements. We perceived the strategy not only as an application of a research tool used by the Swedish partner, but especially as a new strategy of obtaining information about the LM, based on a partner relationship between organizations and institutions on the LM. The strategy used responds to the rapidly changing demands of the LM, its differentiation and the need to better interconnect the private and public sector organizations, institutions on the LM, their clients and LM experts. 
In context of measuring employers' requirements, there are standard measurement categories used, such as occupational structure, vacancies or training. Cedefop (2013) suggests an alternative approach, using tasks as a key measurement category which is closest to our strategy.

An integral part of the research consisted of a feasibility pilot testing and using the most important elements of the Swedish methodology, above all the semi-structured interview in relation to the surveyed employers. Interviews thus became the basic tool for collecting information on LM requirements, conducted by representatives of $\mathrm{LO}$ with representatives of employers in the private and public sectors of a given region. The project implementation team decided to implement the pilot survey in the South Moravian Region (JMK).

An important aspect of the survey also features the fact that the objectives and outcomes of enquiries carried out in the past were known to the employers and HR professionals, which helped overcome their initial mistrust (if any). Another purpose of the personal encounter and conducting of interviews was to overcome the limits of a periodically implemented questionnaire survey and capture the current changes in the LM situation within the organizations.

The research interviews were carried out on the territory of the South Moravian Region. The region of JMK was selected mainly because in this territory there is a long term experience with both qualitative and quantitative LM research. However, it was not possible, necessary or advisable to involve all organizations and employers in this area in the survey. Therefore, we decided to conduct the interviews within a created sample group (SG), whose representation of the situation on the LM in the JMK territory would be as authentic as possible from a structural point of view.

Tab. 2 - The Structure of the Sample. Source: own elaboration

\begin{tabular}{|l|c|c|c|c|}
\hline $\begin{array}{l}\text { Organisations by } \\
\text { number of employees }\end{array}$ & $\begin{array}{c}\text { Number of } \\
\text { organizations in the } \\
\text { JMK region }\end{array}$ & Sample & Coverage rate & Rejection rate \\
\hline $10-49$ & 5486 & 144 & $2.6 \%$ & $18.1 \%$ \\
\hline $50-249$ & 1214 & 36 & $3.0 \%$ & $27.8 \%$ \\
\hline $250+$ & 228 & 20 & $8.8 \%$ & $5 \%$ \\
\hline Total & 6928 & 200 & & \\
\hline
\end{tabular}

In order to create such a sample group, we predetermined several criteria that reflected the most important characteristics of the LM in the JMK region. These criteria related to the region, the size and main activities of the organizations. The selection was based on a database created by the LO of the JMK region as a part of its annual questionnaire survey of the workforce in the JMK region.

The sample group included 200 organizations in the business and public sectors in the districts of Brno - City, Brno - Country, Blansko and Hodonín. In every district, the largest employers were preferred, since their demand for labour is expected to be the highest; however, interviews were also carried out in medium and small-size organizations. Emphasis was placed on the specificities of the sectorial composition of the national economy in the JMK region with regard to 
its advanced agriculture and viticulture. If any of the organizations was unwilling or unable to participate in the research, another similar organization was added into the SG complying with the defined criteria. The rejection rate was up to $28 \%$ in the category of medium-size companies (50 - 249 employees).

In the preparatory phase, the interview was tested in the field in July 2013 and consequently modified to the final version, which was then the version used by the interviewers. The content of the interview is a combination of Swedish scenarios of an interview with employers and the Czech scenarios of a questionnaire survey carried out in the JMK. The key topics included the current economic and personnel situation of the company or institution, the expected development of number of employees within one year and evaluation of the labour market in terms of adequate labour supply in the past six months. A significant part of the interview was devoted to the list of professions most often demanded by the employer and to the description of the expected competencies a job-seeker needed to perform assigned tasks. At the end of the interview, respondents were asked to try to guess what profession and competence will be important for their company or institution in three years. Field work took place in October and November, with the last interviews being conducted in December 2013 or in early January 2014. Very often the organizations would postpone the date of the interview.

All interviews were conducted by experienced staff of the JMK Labour Office or by project professionals. The interviewing usually took about $45 \mathrm{~min}$., beside the time spent organizing the meeting. The structure of the interview is attached in the Appendix. Interviews were recorded on site and later converted into electronic form, on the basis of which a database of organizations, professions and competencies was created.

It has been apparent that organizations differ in their recruitment process, but we did not provide any preliminary hypothesis in this pilot investigation.

\section{DATA PROCESSING AND INTERPRETATION}

The very first step in the analysis was the transcript of record sheets into data sheets. At this stage the interviewers were supposed to specify the demanded professions and competencies as much as possible in order to allow their subsequent division into categories. These categories of professions were assigned by a team of professionals after the completion of the interviews. Inclusion in an appropriate category was based on the following criteria: a) internal structure of the requirements on the demanded workforce, b) similarity of the main activities of the organization, c) the skill level required for the demanded profession. The categories were being created in cycles; in fact the process took form of a multi-stage expert decision-making. The level of skills denotes the difficulty of knowledge and skills requirements, corresponding to a specific level of education needed to perform the duties and responsibilities at work (cf. CZ-ISCO, ISPV, 2012). Professions not matching any of the categories were analysed further.

The second step of the analysis was the transfer of data sheets into the data matrix, where we were able to analyse the profession and related employers' requirements. This data matrix was used to quantify the relations between organizations, professions and employers' requirements, being more qualitative in nature. 
Tab. 3 - Categories of professions. Source: own elaboration.

\begin{tabular}{|l|c|l|c|}
\hline Profession & No. & Profession & No. \\
\hline Administrative staff & 17 & Driver & 19 \\
\hline Electrical engineer & 7 & Warehouseman & 15 \\
\hline Constructor & 10 & Welder & 8 \\
\hline Chef & 10 & Technician & 11 \\
\hline Laboratory assistant & 5 & Technologist & 4 \\
\hline Doctor & 9 & Accountant & 8 \\
\hline Motor vehicle mechanic & 4 & Elementary school teacher & 8 \\
\hline Fitter & 4 & Cleaning worker & 5 \\
\hline Sales representative & 25 & Manufacturing worker & 27 \\
\hline Metalworker & 8 & Locksmith & 5 \\
\hline Security guard & 8 & Nurse & 5 \\
\hline Educational worker & 9 & Mason & 5 \\
\hline Position in management & 16 & Other & 18 \\
\hline Shop assistant & 13 & Total & 269 \\
\hline
\end{tabular}

The next step comprised a certain reduction of information in order to allow for further processing. It was not possible to classify all of the demanded professions into categories. Categories with a frequency of less than 4 and categories with insufficient internal cohesion were excluded. Some categories may seem too broad, such as "manufacturing worker" or a "position in management". However, even these categories have an obvious internal link. For the manufacturing worker it is the requirement for manual dexterity, and for the management it is managerial and organizational abilities. It should be added that the organizations demanded mostly the lowest managerial positions.

Employers' requirements focused mainly on education, professional qualifications (various types of certifications or licenses) and experience as well as on the character traits of the demanded workforce. To a certain extent, the employers used terms related to competencies.

The categorization of the requirements was implemented by the expert team in a similar way as the categorization of professions - via multi-stage decision-making. Therefore these created categories of skills differed from the central database of skills contained in the National Occupational Framework (cf. NSP, 2014).

The tables only contain selected categories of employers' requirements, many of which were formulated in various modifications depending on the particular job position characteristics. As shown in other tables, some requirements are bound specifically to a particular profession.

\section{FINDINGS AND DISCUSSION}

The organizations searched for a relatively small number of workers with the vast majority demanding only individuals. The required staff was mainly supposed to occupy working positions 
already created or newly vacant job positions. Private sector companies particularly expressed a high amount of uncertainty with regard to the economic development in the future and to the possible transfer of production activities abroad, affecting their demand for labour. Concerning the future development of the company and related workforce needs, $60 \%$ of organizations expected to retain their number of employees in the following year, a quarter expected a slight increase and approx. $10 \%$ expected a drop in the number of employees; the rest of employers were not able to predict their development in the future.

The information provided by HR managers and specialists of the companies on the required competencies was quite varied. They were mostly unfamiliar with term "competency" and did not use it spontaneously; they rather mentioned their requirements on the workforce. These requirements are based on the employers' needs. These needs vary, and thus vary the requirements. Nevertheless, we were able to identify the requirement characteristics for each category of professions. For chefs and security guards the requirements included reliability, responsibility, conscientiousness and carefulness; reliability together with pleasant manners were highly required from shop assistants. For doctors and teachers, emphasis was naturally placed on education and communication skills; for educational workers (working with children mostly outside the classroom) and constructors creativity was required, however we supposed that in those two cases a different kind of creativity was meant. For warehouse staff, a forklift driver's license is often required, (professional qualification), but also the ability to work with a PC. For manufacturing workers the skill requirements were low, if any, and a vocational certificate was the only concern. In manufacturing workers, more than in other categories, the employers required the desire and will to work and to attend the workplace in a regular and timely manner.

Requirements on character traits often combined and complemented each other, for example criminal integrity, credibility and reliability required for jobs comprising less demanding manual or non-manual work (warehousemen, cleaning personnel, shop assistants). In our view, associating of the employers' requirements was not coincidental. It illustrates what kind of personality the employers were seeking or missing.

Tab. 4 - Most common general requirements of employers. Source: own elaboration.

\begin{tabular}{|l|l|}
\hline Time flexibility & Experience \\
\hline Empathy, customer orientation & Pleasant manners \\
\hline Physical condition, health eligibility & Readiness to learn \\
\hline Communication and presentation skills & Driving license, category B \\
\hline Creativity & Ability to work in a team \\
\hline Managerial and organizational abilities & Reliability/responsibility \\
\hline Manual dexterity & Vocational certificate \\
\hline Multiple skills & Ability to work with a PC \\
\hline Business skills & Knowledge of specialized software \\
\hline Vocational training & Knowledge of a foreign language \\
\hline Work commitment & Knowledge of technology and materials \\
\hline
\end{tabular}


Multiple skills: This category includes requirements considered by the employers as important for occupancy of a given position, however exceeding the usual requirements in the area of experience, qualifications or skills. An example would be the fact that for the drivers' profession a crane operating license is required or the diverse requirements for administrative staff: from forklift truck driver's license to the knowledge of European funds.

Tab. 4 intentionally does not state the frequency of cited requirements, since their importance for employers varies according to the demanded position and each category of professions forms a characteristic set. As far as the improvement of LM institutions' cooperation is concerned, an important aspect for developing cooperation between the labour offices and employers lies in a successful process of filling vacancies with adequate job seekers, which is one of the most important services expected from labour offices by the employers, as shown in the example of Sweden (Klimplová, 2007). Since 2006, the Swedish active LM policy and its measures have been more focused not only on job seekers but also on employers.

Tab. 5 - Requirements in most demanded professions. Source: own

\begin{tabular}{|l|c|l|c|}
\hline CLERK/OFFICER (18) & Freq. & MANAGEMENT (16) & Freq. \\
\hline PC knowledge & 10 & Leadership & 16 \\
\hline Professional education & 8 & Effective communication & 15 \\
\hline Multi skills & 6 & Professional education & 12 \\
\hline Foreign languages & 6 & Working experience & 10 \\
\hline & & Co-operation & 10 \\
\hline SALES REPRESENTATIVE (25) & Freq. & WAREHOUSE KEEPER (15) & Freq. \\
\hline Effective communication & 19 & Reliability/Responsibility & 13 \\
\hline Customer orientation & 16 & Forklifts license & 10 \\
\hline Professional education & 11 & Health eligibility & 7 \\
\hline Driving license B & 9 & Flexibility & 5 \\
\hline Foreign languages & 9 & PC knowledge & 5 \\
\hline Co-operation & 8 & Multi skills & 4 \\
\hline DRIVER (19) & Freq. & PRODUCTION WORKER (27) & Freq. \\
\hline Driving license (suitable) & 17 & Working experience & 13 \\
\hline Health eligibility & 13 & Reliability/Responsibility & 13 \\
\hline Customer orientation & 12 & Vocational certificate & 13 \\
\hline Life-long learning & 11 & Manual dexterity & 11 \\
\hline Flexibility & 5 & Multi skills & 11 \\
\hline Reliability/Responsibility & 5 & Flexibility & 10 \\
\hline & & Life-long learning & 10 \\
\hline
\end{tabular}

The Labour Offices primarily strive for effective communication and cooperation with employers. The priorities are:

a) to gain best possible knowledge of job vacancies - the better the information on vacancies the labour offices have, the more successful the "matching" process can be; 
b) opening and widening the possibilities of staying in touch with the employers, i.e. Provide information on the LO services at the meetings of employers (use all opportunities and contacts to inform about LO services, especially in sectors with a shortage of workers); take into account the employers' priorities in contact with them (e.g., time constraints) etc.;

c) orienting the contacts with employers towards employment policy, i.e.. obtaining more vacancies or practice placements, having a good understanding of professional competencies of the unemployed and of the changing demand for such competencies in the LM, knowing the employers' requirements and selecting truly suitable candidates for a job position, and thus preventing complaints and the subsequent lack of interest in the LO services (Klimplová, 2007).

Basic findings about the requirements in most demanded professions are shown in Tab. 5, number of identified vacancies is in brackets.

There are many investigations about competencies, many of them are oriented on education, others are describing the existing labour force, e.g. Workforce Acquisition Competency Survey (FAI, 2010, 2012). A very similar survey (Kowal et al., 2010) carried out in Lower Silesia, Poland, among HR professionals, points out serious barriers and difficulties in the work recruitment process such as lack of candidates' work experience (49\%), but only $11 \%$ for the inability to work in a team, $9 \%$ for lack of interpersonal skills and 7\% for lack of foreign language skills.

These findings highlight in a broader perspective the emerging requirements for flexible adaptation of a large part of the workforce. On the supply side, this requires a change supported by coordinated efforts of both intermediary but also educational institutions. At the same time, it is necessary to create and implement systems of institutional cooperation corresponding to practical requirements and exceeding the current requalification and other tools of active employment policy. These include learning in a professional context (cf. Novotny, 2006) and innovative ways of professional preparation. Besides, this is represented by the category "Readiness to learn", assigned to a wide range of professions.

\section{CONCLUSIONS}

The employers' requirements on the workforce have various definitions. HR professionals in companies formulate these requirements and bring them to the open LM, with the public employment institutions being only one of the options to link the supply and demand on the LM. In our research, this exemplifies the fact that employers use the Labour Offices to search for workers for work categories usually characterized by lower work complexity, prevailing manual work and lower education and intellectual capacity requirements. These are mostly manufacturing professions or trade and operating workers in the area of services, such as logistics or surveillance of buildings.

If more demanding specialist positions were sought, it concerned professions such as constructors and technicians in the manufacturing sector, while the non-manufacturing sector offered vacancies for doctors, nurses, teachers and educational workers. Required positions in management consisted of demand for employees at the lowest levels of management, such as shift super- 
visor, plant manager and production foreman. Higher level managers' positions were probably occupied in a manner different from the open LM.

According to our observations, companies adapt to the significant excess of workforce supply over demand. It is increasingly common that larger and even smaller companies keep their own database of candidates. More often, job seekers contact them directly, without the LO public servant. They visit the companies in person or send their CVs.

Larger companies for example employ a model based on using agency workforce. The company tests the new employee as an agency employee, and if he or she passes, he or she obtains standard employment. It is a way to avoid the risk of a wrong choice and the costs associated with resolving the situation.

In this context, a level of basic qualities that were hard to define appeared very often and were mentioned between the soft competencies and character traits ("be willing to work", "have natural intelligence", "must like the work they are doing"). As is apparent from interviews, especially small and medium size companies shift the emphasis of recruiting towards these qualities. In this context the importance of informal relations and various recommendations grows.

It is promising that HR professionals are able to clearly formulate the requirements of their organizations and that they partially even use terms connected to competencies. This is in contrast to smaller size companies without the position of a specialized HR professional, where requirements are vague - if the company had a vacancy at all. As already mentioned, filling the vacancies in these companies depended on their environment and on informal networks, where they sought suitable staff without the need to contact the LM institutions. In a way this limits the development of cooperation between various institutional LM actors.

A number of issues relating to the employers' requirements, required competencies, their categorization in the National Occupational Framework and flexible filling of vacancies with the unemployed remains unresolved, however the basic research objective was met. The possibility of using the Swedish methodology to identify requirements on the LM in the Czech environment was verified and we also obtained information relevant for LM institutions, especially the LO and also for the social partners and other state and local administration bodies. We hope that the LO will go on with this type of surveys, because identification of competencies should be useful for an effective matching process of demand and supply of labour force by LO officers.

\section{Acknowledgements:}

This study was supported by the ESF within the Active Matching project OP LZZ/5.1/77/00400.

\section{References}

1. Bowman, J., West, J. \& Beck, M. (2009). Achieving Competencies in Public Service. London: M. E. Sharpe.

2. Cedefop (2009). The dynamics of qualifications: defining and renewing occupational and educational standards. Luxembourg: Office for Official Publications of the European Communities.

3. Cedefop (2013). Piloting a European Survey on Skill Needs. Illustrative Findings. Luxembourg: Publications Office of the European Union 2013. Retrieved September 24, 2014, from http://www.cedefop.europa.eu/EN/Files/5536_en.pdf 
4. Dubois, D. \& Rothwell, W. (2004). Competency-Based Human Resource Management. Mountain View, California: Davies-Black Publishing.

5. Durkheim, É. (2004). Společenská délba práce. Brno: Centrum pro studium demokracie a kultury.

6. Federal Acquisition Institute. (2010). Acquisition Workforce Competency Survey Results Report. Washington: FAI.

7. Federal Acquisition Institute. (2012). Acquisition Workforce Competency Survey Results Report. Washington: FAI.

8. Guthrie, H. (2009). Competence and competency based training: what the literature says. Adelaide: National Centre for Vocational Education Research.

9. Horton S., Hondeghem A. \& Farnham, D. (Eds.). (2002). Competency management in the public sector. Amsterdam, Berlin, Oxford, Tokyo, Washington DC: Instituut Yoor de Overheid.

10. ISPV. (2012). Metodika CZ-ISCO. Retrieved June 6, 2014, from http://www.ispv.cz/cz/ Metodicke-centrum-CZ-ISCO.aspx

11. Kalousková P. \& Vojtěch J. (2008). Potréby zamèstnavateli̊ a pripravenost absolventů škol-soubrnný př́bled. Praha: NÚOV. Retrieved April 4, 2014, from http://www.nuov.cz/uploads/ Vzdelavani_a_TP/Potreby_zamestnavatelu_souhrn.pdf

12. Kanfer, R. \& Ackerman, P. (2005). Work Competence. A Person-Oriented Perspective. In Handbook of Competence and Motivation. (Elliot, A. \& Dweck, C., ed.), NY: The Guilford Press.

13. Klimplová, L. (2007). Švédská politika zaměstnanosti včera a dnes. In Sociální reprodukce a integrace: ideály a meže. (Mareš, P. \& Hofírek, O., pp. 101 - 118) Brno: Masarykova univerzita.

14. Klimplová, L. (2010). Př́ležitosti a bariéry spolupráce zaměstnavatelů a úřadů práce z pohledu zaměstnavatelů. In Nová sociálni rizike na trbu práce a potréby reformy české veréjné politiky. (Winkler, J. \& Klimplová, L. (eds.), pp. 140 - 158) Brno: Masarykova univerzita.

15. Kowal,,J., Kwiatkowska, A. \& Patro, I.(2010). The Prospects of Graduates'Career Development in Poland: The Example of the Competence Survey in Lower Silesian Region 2006 - 2010.

In: Proceedings of the 6th European Conference on Management Leadership and Governance. Wroclaw: College of Management Edukacja.

16. Moore, D., Cheng M. \& Dainty A. (2002). Competence, competency and competencies: performance assessment in organisations. Work study, 51(6), 314-319. http://dx.doi.org/10.11 08/00438020210441876

17. MŠMT, no date: Kompetenčni model - druby kompetencí. Retrieved April 2, 2014, from http:// www.nuov.cz/uploads/Kompetencni_model_Kompetence_specificke.pdf

18. Mulder, M., Weigel, T. \& Collins, K. (2007). The concept of competence in the development of vocational education and training in selected EU member states: a critical analysis. Journal of vocational education and training, 59(1), 67-88. http://dx.doi.org/10.1080/136 36820601145630

19. Národní soustava povolání. (2014). Centrální databáze kompetencí. Praha: NSP. Retrieved June 24, 2014, from http://kompetence.nsp.cz/napoveda.aspx 
20. Novotný, P. (2006). Lidské zdroje, celoživotní učení a vzdělávání v pracovním a profesním konextu. Studia Paedagogica, 54(11), 27 - 40.

21. Pilařová H. (2009). Osobnost 3. - Charakter - definice, složky, vlastnosti, charakter zdravotníka. Retrieved April 2, 2014, from http://wiki.rvp.cz/Kabinet/Ucebni_texty/ Psychologie_pro_st $\%$ C5\% $\% 99 \mathrm{edn} \% \mathrm{C} 3 \%$ AD_\%CC5\%A1koly/Osobnost_3._-_charakter__definice,_slo\%C5\%BEky,_vlastnosti,_charakter_zdravotn $\% \mathrm{C} 3 \% \mathrm{ADka}$

22. Strandberg, H., Strannefors, T. \& Sundqvist, J. (2006). Skill Needs Analysis Manual. Stockholm: Swedish National Labour Market Board.

23. Teodorescu, T. (2006). Competence versus competency: What is the difference? Performance improvement, 45(10), 27-30. http://dx.doi.org/10.1002/pfi.4930451027

24. Thomas, J. (2010). Specialty Competencies in Organizational and Business Consulting Psychology. NY: Oxford University Press.

25. Veteška, J. \& Tureckiová, M. (2008). Kompetence ve vždělávání. Praha: Grada Publishing.

26. Winkler, J., Klimplová, L. \& Vrbková, K. (2008). Proč jsou zaměstnavatelé (ne)spokojení s činností úřadu práce? Sociálne a politické analýzy, 2(1). 39-71.

\section{Contact information}

Mgr. Josef Horñáček

Masaryk University, Faculty of Social Studies

Joštova 10, 60200 Brno, Czech Republic

Email:65219@mail.muni.cr.

Mgr. Iveta Zelenková, PhD.

Masaryk. University, Faculty of Social Studies

Joštova 10, 60200 Brno, Czech Republic

Email: ivetkazelenkova@seznam.cz. 


\section{APPENDIX}

\section{Structure of the interview}

Matching of Competences

Date :

Sheet No.:

Company: ID

Location: Branch of Industry:

Number of employees Manual Workers Turnover Agency Workers

1) What is your opinion about the current economic and employment situation of your office / branch / plant?

2) Have you noticed a lack of suitable candidates for filling vacancies in the last six months? If no, go to question 4.

3) What was the lack of individual professions? Have you filled the gaps in recruitment through agencies or Employment Office?

4) Do you think that in the next year you will have:

a) more employees

b ) the same number of employees

c) less employees

Why do you think so?

5) If you plan on recruiting staff, what positions will they be?

a) Key positions - workers in the direct performance

b) Management

c) Business Administration

d) Technicians / specialists

e) Seasonal workers

Write down the professions

6) If you think about employee turnover, do you thinking that the employees will be replaced?

a) by workers with the same qualifications and skills

b ) by workers with higher qualifications and skills

c) by workers with lower qualification

d) will not be replaced, we expect the use of technology or rationalization

e) we do not allow for departures

7) Which competencies are you looking for? 
8) Does an employee have any specific behavioural characteristics in the workplace?

9) Try to be a prophet. What competencies will you look for in the next three years? PROFESSION

Do you want to add something?

Thank you for your answers. 